\title{
Effectiveness of vermicompost with additives of various botanical pesticides in controlling Plutella xylostella and their effects on the yield of cabbage (Brassica oleracea L.var. Capitata)
}

\author{
Nurhidayati1 $^{*}$, Masyhuri Machfudz ${ }^{2}$, Abdul Basit ${ }^{1}$, Rose Novita Sari Handoko ${ }^{1}$ \\ ${ }^{1}$ Department of Agrotechnology, University of Islam, Malang, East Java, Indonesia \\ ${ }^{2}$ Department of Agribusiness, University of Islam, Malang, East Java, Indonesia
}

\begin{abstract}
Received:
October 18, 2019

Accepted:

March 01, 2020

Published:

July 30,2020

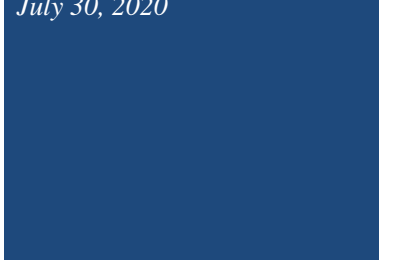

\section{Abstract}

The larva of Plutella xylostella causes damage to cruciferous plants by feeding the tissue between the leaf surfaces. To increase the production of organic cabbage vegetables, it is necessary to develop botanical pesticides. This study aims to describe the effect of vermicompost with additives of various botanical pesticides on the intensity of the moth diamondback attack and cabbage yield. The pot experiment employed randomized block design, with six treatments including plants: (1) without vermicompost and pesticide (control), (2) with synthetic pesticide application (SP), (3) with the application of the mixture of vermicompost and neem $(\mathrm{V}+\mathrm{N}),(4)$ with the application of the mixture of vermicompost and papaya $(\mathrm{V}+\mathrm{P}),(5)$ with the application of the mixture of vermicompost and marigolds leaves $(\mathrm{V}+\mathrm{M}),(6)$ with the application of a mixture of vermicompost and soursop leaves $(\mathrm{V}+\mathrm{S})$. Each treatment has five replications and three pot samples per replication. The results showed that at the end observation of attack intensity of $P$. xylostella, treating cabbage with marigold leaves $(20.26 \%)$ and soursop leaves $(17.50 \%)$ had the same effectiveness with synthetic pesticide $(21.86 \%)$ and significantly different with the other treatments $(\mathrm{P}<0.05)$ by intensity attack of $29.69 \%$ (neem leaves) and $24.31 \%$ (papaya leaves). Treating cabbage with either soursop leaves or marigold leaves increases the size of the cabbage head, marketable yield, fresh weight and dry weight of biomass total and significantly different from the other treatments $(\mathrm{P}<0.05)$. The results suggest that application of vermicompost with botanical pesticide additives is effective to control P. xylostella in the production of organic vegetables.
\end{abstract}

Keywords: Vermicompost, Botanical pesticides, Plutella xylostella, Cabbage

\section{How to cite this:}

Nurhidayati, Machfudz M, Basit A and Handoko RNS, 2020. Effectiveness of vermicompost with additives of various botanical pesticides in controlling Plutella xylostella and their effects on the yield of cabbage (Brassica oleracea L.var. Capitata). Asian J. Agric. Biol. 8(3):223-232. DOI: https://doi.org/10.35495/ajab.2019.10.436
*Corresponding author email: nurhidayati@unisma.ac.id
This is an Open Access article distributed under the terms of the Creative Commons Attribution 3.0 License. (https://creativecommons.org/licenses/by/3.0), which permits unrestricted use, distribution, and reproduction in any medium, provided the original work is properly cited. 


\section{Introduction}

The horticultural plant cabbage (Brassica oleracea L.) has been an economic role in Asia and Africa (Grzywacz et al., 2010). Cabbage yields are greatly influenced by environmental factors such as climate, pests and plant diseases, etc. The Plutella xylostella $L$. (Lepidoptera: Plutellidae) also known as diamondback moth is an important insect pest which is oligofag prominently to the family of Brassicaceae (Liu et al., 2002; Liang et al., 2003; Sarfraz et al., 2006) and thus damage crops. The population of $P$. xylostella is influenced by abiotic and biotic factors such as rainfall, temperature, host plant, natural enemies and cultural methods, especially in vegetable crops. Their presence can cause high production losses leads to a decrease in income earned by farmers, thus threatening the sustainability of small farmers whose income is entirely dependent on their production (Sow et al., 2013). Chemical pesticides used to control P. xylostella populations can introduce undesired side effects on the environment, such as environmental pollution and the reduction of natural enemies of $P$. xylostella. It also endangers the farmers not only due to the possibility of improper handling but also the ever-increasing cost of pesticides (Talekar and Shelto ,1996; Dobson et al. 2002). Furthermore, the use of pesticides leads to the development of resistance in pest, results in the use of stronger and more toxic chemicals to kill pest on pest resurgence. The extensive use of pesticides is not a sustainable solution for pest control. Environmental friendly management using organic fertilizers against $P$. xylostella is an alternative way. The organic fertilizers can increase the populations of beneficial microorganisms in the soil that act as the natural enemies of $P$. xylostella.

One of the high-quality organic fertilizers is vermicompost, produced by the activity of earthworm, forms integral sustainable agriculture (Calabi-Floody et al., 2018). During the vermicompost manufacturing process, earthworm release excretion which increases the quality of vermicompost. Earthworm casts are rich in nutrients that increase the population and activity of microorganisms in the soil, however, the activity of earthworm can negatively affect pathogens. The vermicompost is healthier than other organic fertilizers such as conventional compost using organic waste and manure from the animal residue (Asgharnia, 2003; Lazcano and Domínguez, 2011), however, the quality of vermicompost is varying depending on the raw material use and vermicomposting process. The increasing demand for organic products has created an impetus to find pesticides that are safer, more effective and biodegradable. Many tropical medicinal plants have been used for plant protectionism. The plants of different families, genera, and species are contained sources of bioactive organic compounds. The compounds of alkaloids, sesquiterpene, lavonoids, limonoids, phenols, coumarins, stilbenes derived from plants are known to have toxic, antifeedant, repellent, and plant growth regulators against various types of food crop pests and horticulture (Mwanauta et al., 2014). Pesticides derived from natural ingredients have been attracted tremendous interest because they are environmentally friendly. They can substitute synthetic pesticides in pest management (Thakore, 2006; Glare et al., 2012; Dutta, 2015). Further, natural enemies will still exist or not die because of the management of plant-based pesticides (Schmutterer, 1997). Plant pesticides positively influence the development of integrated pest management systems as pest control. Research and application in agriculture that uses plant extracts is a step to protect plants and the environment from chemical pesticides (Prakash and Rao, 1997). In addition to low levels of mammalian toxicity, they have a minimal impact on non-target organisms, readily available and more costeffective than chemical pesticides (Prakash and Rao, 1997). Further, botanical pesticides only focus on pests and have no impact on natural enemies, which is a beneficial condition for agroecosystem sustainability.

However, the effectiveness of a different types of botanical pesticides varies because they exhibit a range of biological activities, namely repellents, insecticides, fungicides, nematicides, and bactericides (Isman, 2006). Each type of botanical pesticide contains different active compounds, thus, their mechanism in controlling plant pests are different. This research focused on the use of botanical pesticide as a vermicompost additive to enhance its effects in reducing the activity of pest. This study aimed to illustrate the effect of vermicompost with additives of various botanical pesticides on the attack intensity of diamondback moth and the cabbage yield.

\section{Material and Methods}

A pot experiment was conducted in January - May 2018 at the greenhouse of the Faculty of Agriculture, 
University of Islam, Malang, East Java, Indonesia with an altitude of 545 meters above sea level and temperature ranged from $22.7^{\circ} \mathrm{C}$ to $30^{\circ} \mathrm{C}$. We adopted randomized block design, with six treatments including plants: (1) control: without application of vermicompost and pesticide, (2) with application of synthetic pesticide (SP) only (3) with application of vermicompost and neem leaves $(\mathrm{V}+\mathrm{N})$ mixture (4) with application of vermicompost and papaya leaves $(\mathrm{V}+\mathrm{P})$ mixture (5) with application of vermicompost and marigolds (Tithonia diversifolia) leaves $(\mathrm{V}+\mathrm{M})$ mixture and (6) with application of vermicompost and soursop leaves $(\mathrm{V}+\mathrm{S})$ mixture. Each treatment had five replications, with three pot samples per treatment for observation. Each pot had one cabbage plant. Thus, there was 90 pots in this experiment.

The making of vermicompost was carried out in the compost laboratory of the Faculty of Agriculture, University of Islam Malang. The materials used for making vermicompost were organic residues (cow dung, vegetable residue from traditional markets, and leaves litter) as earthworm feed and cocopeat as bedding, vermicomposting bin and earthworm Lumbricus rubellus as decomposers. Materials from organic residues were mixed evenly. The bedding was placed at the bottom and at the top of the vermicomposting bin. Earthworm feed was placed in the middle. The vermicomposting process lasted for four weeks while maintaining the media moisture content of $80 \%$. After the vermicomposting process, the earthworms L. rubellus were separated from vermicompost. Furthermore, the vermicompost was composted aerobically for 14 days with the addition of fishbone mill and eggshell flour. Prior to use, all of the botanical pesticides leaves (neem, papaya, marigold, and soursop leaves) were dried and chopped. After that, they were mixed with the vermicompost by $2.5 \mathrm{wt} \%$ (weight percent) of vermicompost which used in each treatment.

The type of soil used in this study was Inceptisol with Nitrogen content $(0.18 \%)$, organic matter content (2.20\%), pH (5.68), carbon (1.69), P-Bray 1 (17, 46 $\mathrm{mg} / \mathrm{kg}), \mathrm{K}_{2} \mathrm{O}\left(28.40 \mathrm{mg} \mathrm{kg}^{-1}\right), \mathrm{C} / \mathrm{N}$ ratio (9.35), sand content (28.4\%), silt content (34.5\%), and clay content $(37 \%)$ with textured clay loam. The growing media used were a mix of soil and cow dung with a ratio of $4: 1$ and a total weight of $10 \mathrm{~kg}$. The vermicompost was applied at a dose of $200 \mathrm{~g}$ per pot. The vermicompost application was divided into two parts. One hundred grams of vermicompost was incorporated into the growing media one week before transplanting. The other one hundred grams was sprayed as liquid organic fertilizer by mixing $100 \mathrm{~g}$ vermicompost in one liter water for one week and vermicompost solution was filtered and sprayed on the leaves surface to control Plutella xylostella when the age of cabbage plant was three weeks after transplanting with 3-day intervals. Cabbage seeds were sown for 21 days, then transplanted into the growing media. There was one cabbage plant per pot. Cabbage plants were introduced to $P$. xylostella caterpillar ( $\mathrm{n}=3$ per plant, their instar phase) at the age of two weeks after transplanting. During growth, cabbage was watered every day until field capacity. The control treatment (SP) used $10 \mathrm{~kg}$ of soil with the application of N-P-K fertilizer (15-15-15) with a dose of $500 \mathrm{~kg} \mathrm{ha}^{-1}(2.5 \mathrm{~g}$ per pot). Dupont Prevaton, a common synthetic pesticide for $P$. xylostella, was used in the control treatment (SP).

The percentage scale of damage caused by $P$. xylostella is categorized in Table 1 . The variables observed were the attack intensity of $P$. xylostella caterpillar pests, namely by the formula:

$$
\mathrm{I}=\frac{\sum(\mathrm{n} \times \mathrm{v}) \times 1}{\mathrm{~N} \times \mathrm{Z}} 100 \%
$$

Remark:

I: Intensity of attack (\%)

$\mathrm{n}$ : Number of samples on the score damage

$\mathrm{v}$ : Score damage to the sample

$\mathrm{N}$ : Total number of sample

Z: Highest score of categories attack

(Angraeny et al.., 2018; Hamid et al., 2018)

Table-1. Categories of attack intensity of $P$. xylostella

\begin{tabular}{|c|c|}
\hline Score Damage & Damage Percentage (\%) \\
\hline 0 & 0 \\
\hline 1 & $1-25$ \\
\hline 2 & $26-50$ \\
\hline 3 & $51-75$ \\
\hline 4 & $76-100$ \\
\hline
\end{tabular}

Source: Angraeny et al. (2018); Hamid et al. (2018)

The observed yield variables consisted of fresh weight of total biomass by plant, dry weight of total biomass by plant, the weight of marketable yield and head diameter of cabbage per plant. 
The collected data were statistically confirmed using analysis of variance (F Test) at $\mathrm{P}<0.05$ and treatment was determined by Tukey test $(\mathrm{P}<0.05)$ using Minitab Version 14.12. Microsoft Excel was employed for statistical analysis of data. Correlation analysis was performed to determine the effect of the intensity of pest attacks on crop yields. The result of correlation analysis was tested by $\mathrm{F}$ test $(\mathrm{P}<0.05)$.

\section{Results}

Effect of vermicompost in combination with various botanical pesticides on attack intensity of Plutella xylostella

Vermicompost in combination with various botanical pesticide additives significantly affected the intensity of pest attacks on cabbage in all observations. Table 2 shows almost all treatments using vermicompost with biopesticide additives had lower significantly attack intensity than the control and synthetic pesticide treatments. However, the SP treatment shows either lower or not different attack intensity with some treatments added vermicompost mixture with botanical pesticide at 26-34 dap. The treatment of vermicompost mixture with additives of neem leaves $(\mathrm{V}+\mathrm{N})$ at the beginning of growth from the age of 1624 dap tends to have the lowest attack intensity but not significantly different from the treatment of $\mathrm{V}+\mathrm{P}, \mathrm{V}$ $+\mathrm{M}$, and $\mathrm{V}+\mathrm{S}$.
Effect of vermicompost in combination with various botanical pesticides on cabbage yield

Significant differences in cabbage yields were observed for the treatments $(\mathrm{P}<0.05)$. Overall, vermicompost with marigold $(\mathrm{V}+\mathrm{M})$ and soursop $(\mathrm{V}$ $+\mathrm{S})$ leaves gave the highest yield characteristics compared to the other treatments (Fig 1).

\section{Effect of Plutella xylostella attack intensity on the yield of cabbage}

The attack intensity of the $P$. xylostella pest affects the yield parameters of cabbage. Fig 2 shows the relationship between the attack intensity of P.xylostella with the yield parameters of cabbage plants. The last observation gave a negative correlation coefficient (r). This means that the higher intensity of P.xylostella pests reduces plant yield. The attack intensity of $P$. xylostella pest had the greatest influence on the fresh weight of total biomass per plant with a value of $r=-0,928$, significantly affected the marketable yield $(r=-0,862)$ and dry weight of total biomass per plant $(r=-0,639)$. This decrease in yield was due to the high pest infestation which caused the leaves to perforate, hence the fresh and dry weight of total biomass of cabbage plant decreases. The $P$. xylostella attack also reduced marketable yield, because $P$. xylostella also attacked cabbage head.

Table- 2. Attack intensity of $P$. xylostella at various plant ages due to application of vermicompost with additives of various botanical pesticide

\begin{tabular}{|c|c|c|c|c|c|c|c|c|c|c|c|c|c|c|c|c|c|c|c|c|}
\hline \multirow{3}{*}{\begin{tabular}{|c|} 
Treatments \\
Control \\
\end{tabular}} & \multicolumn{20}{|c|}{ Observation of Attack Intensity of $P$. xylostella $(\%)$} \\
\hline & \multicolumn{2}{|c|}{16 dap } & \multicolumn{2}{|c|}{18 dap } & \multicolumn{2}{|c|}{20 dap } & \multicolumn{2}{|c|}{22 dap } & \multicolumn{2}{|c|}{24 dap } & \multicolumn{2}{|c|}{26 dap } & \multicolumn{2}{|c|}{28 dap } & \multicolumn{2}{|c|}{30 dap } & \multicolumn{2}{|c|}{32 dap } & \multicolumn{2}{|c|}{34 dap } \\
\hline & 22.41 & $\mathrm{~b}$ & 35.07 & $\mathrm{~d}$ & 30.38 & $\mathrm{~b}$ & 28.21 & $\mathrm{c}$ & 24.49 & $\mathrm{~b}$ & 27.36 & $\mathrm{c}$ & 28.11 & $\mathrm{c}$ & 25.43 & $\mathrm{~b}$ & 26.34 & $\mathrm{~d}$ & 32.60 & $\mathrm{~d}$ \\
\hline $\mathrm{V}+\mathrm{N}$ & 16.74 & $\mathrm{a}$ & 17.01 & $\mathrm{a}$ & 20.13 & $\mathrm{a}$ & 21.92 & $a b$ & 14.96 & $\mathrm{a}$ & 23.49 & $\mathrm{bc}$ & 22.26 & $\mathrm{~b}$ & 24.03 & $\mathrm{~b}$ & 24.23 & $\mathrm{~cd}$ & 29.69 & $\mathrm{c}$ \\
\hline $\mathrm{V}+\mathrm{P}$ & 19.67 & $a b$ & 17.11 & $\mathrm{a}$ & 19.53 & $\mathrm{a}$ & 19.30 & $\mathrm{a}$ & 22.78 & $\mathrm{~b}$ & 19.81 & $\mathrm{~b}$ & 25.89 & $\mathrm{bc}$ & 20.96 & $a b$ & 19.78 & $a b$ & 24.31 & $\mathrm{~b}$ \\
\hline HSD $5 \%$ & 4.20 & & 4.04 & & 6.75 & & 4.74 & & 5.50 & & 5.75 & & 5.09 & & 6.86 & & 3.21 & & 4.91 & \\
\hline HSD $5 \%$ & 4.20 & & 4.04 & & 6.75 & & 4.74 & & 5.50 & & 5.75 & & 5.09 & & 6.86 & & 3.21 & & 4.91 & \\
\hline
\end{tabular}

Means followed by different letters in the same column are statistically significant different at Tukey- test, $\mathrm{P}=0.05$;

$*$ = significant; $\mathrm{ns}=$ non-significant at Dunnet test, $\mathrm{P}=0,05$

$\mathrm{SP}=$ Sinthetic Pesticide; $\mathrm{V}+\mathrm{N}=$ Vermicompost + Neem Leaves; $\mathrm{V}+\mathrm{P}=$ Vermicompost + Papaya Leaves; $\mathrm{V}+\mathrm{M}$

$=$ Vermicompost + Marigold; $\mathrm{V}+\mathrm{S}=$ Vermicompost + Soursop 

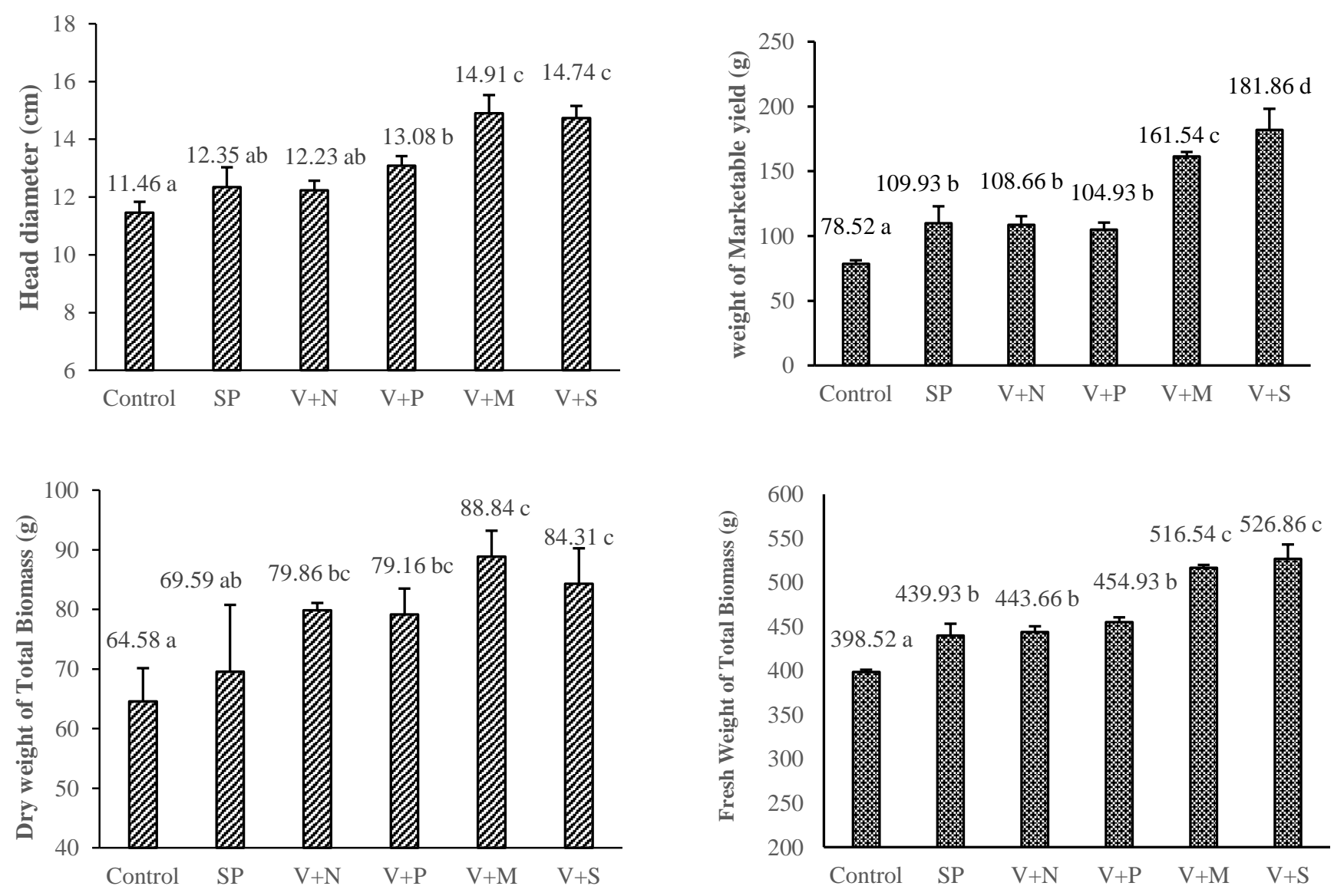

Fig-1: Characteristics of yield of cabbage at harvest (90 dap) on various botanical pesticide compare to synthetic pesticide and control (without pesticide)

\section{Effect of Plutella xylostella attack intensity on the yield of cabbage}

The attack intensity of the $P$. xylostella pest affects the yield parameters of cabbage. Fig 2 shows the relationship between the attack intensity of P.xylostella with the yield parameters of cabbage plants. The last observation gave a negative correlation coefficient (r). This means that the higher intensity of P.xylostella pests reduces plant yield. The attack intensity of $P$. xylostella pest had the greatest influence on the fresh weight of total biomass per plant with a value of $r=-0,928$, significantly affected the marketable yield $(r=-0,862)$ and dry weight of total biomass per plant $(r=-0,639)$. This decrease in yield was due to the high pest infestation which caused the leaves to perforate, hence the fresh and dry weight of total biomass of cabbage plant decreases. The $P$. xylostella attack also reduced marketable yield, because $P$. xylostella also attacked cabbage head.

\section{Discussion}

The vermicompost in combination with various botanical pesticide additives was effective in reducing the intensity of pest attacks on cabbage compared with control (without pesticide). But for comparing with synthetic pesticide, age 26-34 dap found some treatments of vermicompost with botanical pesticide additives show higher effectiveness. Lazcano and Domínguez (2011) reported that vermicompost from various raw materials had a higher nutrient content than conventional compost which can directly influence plant growth. The indirect effect of vermicompost increases plant resistance to pests and diseases attack. The use of vermicompost in the soil can increase microbial activity because vermicompost was made from the fragmentation of organic matter by earthworm ingestion (Lazcano et al., 2008; Ravindran et al., 2015). Increasing the population and activity of beneficial microbes can reduce pest and disease attacks on plants. 

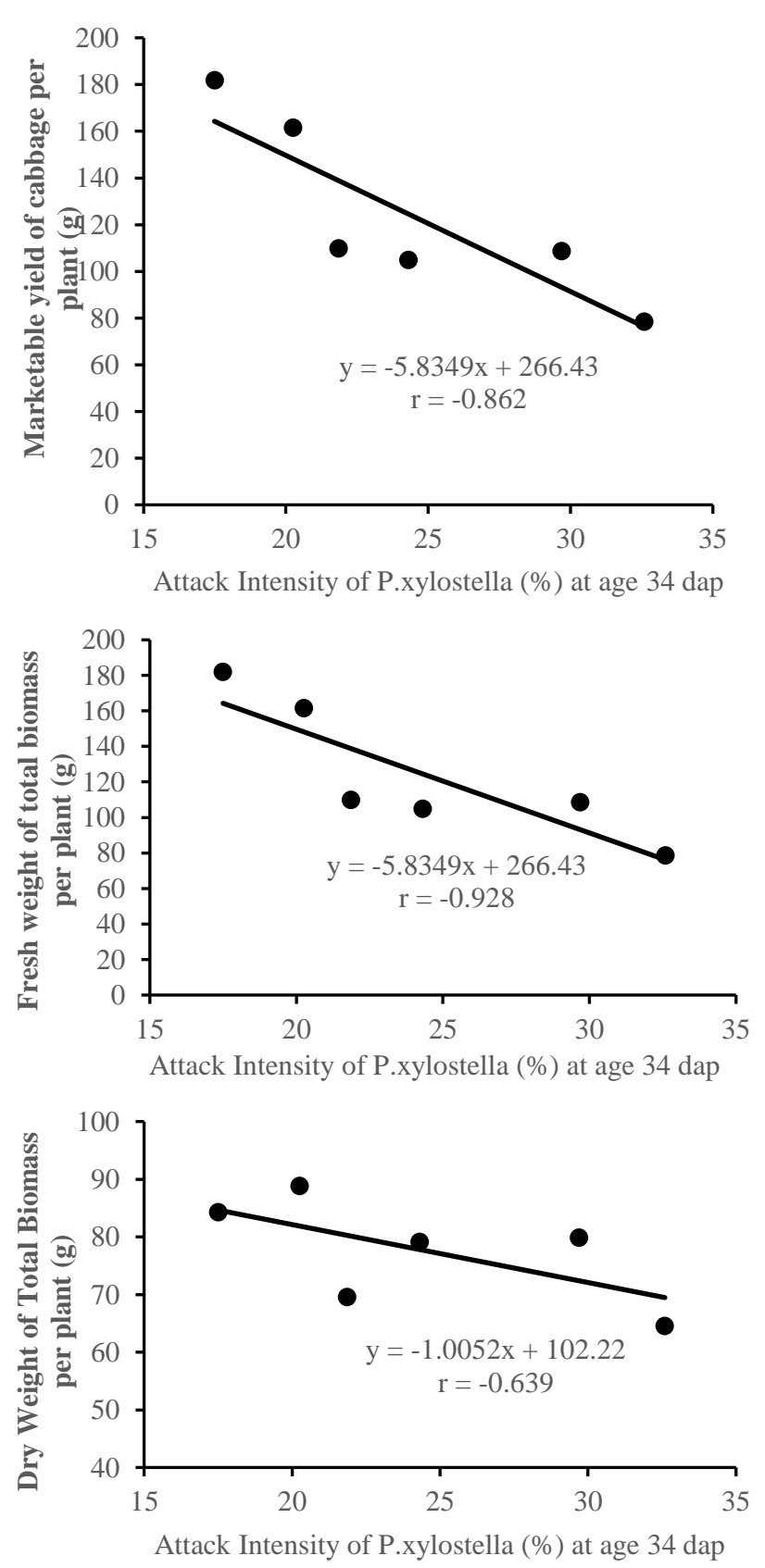

Fig-2: Correlation between attack intensity of $\boldsymbol{P}$. xylostella (\%) at age 34 dap and yield parameters of cabbage

The addition of botanical pesticide material in the vermicomposting process increases the effectiveness of vermicompost in controlling pests and plant diseases. Conventional pesticides are synthetic ingredients that kill or deactivate pests. In contrast, botanical pesticides contained substances that control pests by non-toxic mechanisms. The natural product compounds were called limonids. Limonids in the neem are azadirachtin, salanin, meliantrion and nimbin. These active compounds have been shown to inhibit insect growth. They do not kill insects, but repel, disrupt their growth and reproduction. Natural substances in botanical pesticides work like growth regulators that can resist and attract pests such as pheromones, which can interfere with growth and cause mating disruption (Gupta and Dikshit, 2010; Mikami and Ventura, 2008). Extracts of neem in the study showed significant results on fecundity, pupal weight, other biological and reduced appetite of $P$. xylostella (Ahmad et al., 2012). Another study showed that the neem bioinsecticide affected the fecundity reproductive rates and reduced the emergence of adults in the surviving generation of $H$. Armigera (Ahmad et al., 2015).

At the end of the observation period, the treatment of vermicompost with soursop and marigold (Tithonia diversifolia) leaves gave the lowest attack rate. Jama et al. (2000), reported that the application of green manure $T$. diversifolia could improve soil fertility. Comparison between green biomass from $T$. diversifolia and shrubs, a litter of trees, namely $T$. dirversifolia, has high nutrition. The content of $T$. dirversifolia at dry weight, studied in East Africa, has $3.5 \%$ Nitrogen $(\mathrm{N}), 0.37 \%$ Phosphorus $(\mathrm{P})$, and $4.1 \%$ Kalium (K). Besides containing high nutrients, the traditional use of $T$. diversifolia has been validated through scientific studies (Goffin et al., 2002; Oyewole et al., 2008; Afolayan et al., 2016). Tagitinins is the main bioactive of $T$. dirversifolia as constituents were identified as sesquiterpene lactones (Ferreira et al., 2005; Goffin et al., 2002). The results of the study of Pavela et al. (2018) showed that control of oviposition inhibitors against myths was use in $T$. diversififolia. It contains tagitinin $\mathrm{C}$, the parent molecule of this class of secondary metabolites that has antifeedant activity on the caterpillar Chlosyne lacinia (Lepidoptera) (Ambrosio et al., 2008). On the other hand, the control of the trips attack to suppress the intensity of the attack of green laugies and reduce the population was use soursop (Annona) leaves because contain active chemical compounds of acetogenin. Acetogenin is also insecticidal (antiinsect-worm) and appetite-lowering (Ansante et al., 2015; Ribeiro et al., 2015; Gonçalves et al., 2017; Souza et al., 2017). Annona also has a higher content of flavonoids and phenols. Thus, it has the potential to be developed as botanical insecticides (Freitas et al., 2014). 
Amalia and Yusa (2018) also reported that soursop leaf extract (Annona muricata) was effective as a biopesticide material to control leaf caterpillars $(P$. xylostella) for pomegranate rose apples. Secondary compounds (allelochemicals) that are synthesized and accumulated in plant parts can produce the best insecticidal compounds, called Annonaceae (Ribeiro et al., 2017). Acetogenins (ACG) from the Annonaceae plant has a chemical structure that has the potential as an insecticide or acaricidal (Blessing et al., 2010). In soursop leaf, 18 types of acetogenic proven to be cytotoxic in vitro have been found. They are potential mitochondrial poisons that inhibit cellular energy production (Isman and Grieneisen, 2014). Biopesticide compounds are highly selective against the target organisms. Therefore, the natural predators of the targeted organisms.

This, in turn, enables the plants to carry out photosynthesis optimally and increase the crop yields (Qamar et al., 2017). Baidoo et al. (2012) reported that the reduction in pest attack significantly increased the yield of cabbage without the use of chemical insecticides. Marigold and soursop contain naturally occurring biopesticides which interfere with the growth of insects regulate plant growth, or substances that repel or attract pests, such as pheromones (Koul, 2004; Isman, 2006). The vermicompost application significantly increased plant growth and yield compared to control for all yield parameters measured (Fig. 1). Several previous studies also reported similar results; vermicompost exerts a positive influence on plant growth and yield. The addition of vermicompost to the growing-medium increase the growth and yield of cabbage, broccoli, mustard Pakcoi (Nurhidayati et al., 2016; 2017; 2018). Vermicompost application also suppressed the growth of many parasitic fungi, such as Pythium, Rhizoctonia and Verticillium. Vermicomposts also suppressed plant-parasitic nematodes and enhance the activity of vesicular arbuscular mycorrhizae (Atiyeh et al., 2002; Arancon et al., 2003). This is because vermicompost can improve soil quality, increase the availability of macro and micro nutrients and microbial activity. The vermicomposting process produced high-quality organic fertilizer to stimulate growth, induce flowers and help ripen fruit in plants. Nurhidayati et al. (2017) reported that the addition of fish meal, eggshell flour and biopesticides improved the quality of vermicompost thereby enhancing the effect of vermicompost on plants. Plant growth can be supplied with plant growth regulators (PGR) found in vermicompost. Vermicompost also provided hormonal activity due to the content of the humic substances of vermicompost (Lazcano and Domínguez, 2011).

\section{Conclusion}

The application of vermicompost with botanical pesticide additive had a significant effect on the intensity of $P$. xylostella attacks. Treating cabbage with a mixture of vermicompost and botanical pesticides leaves lower the attack intensity compared to control (without vermicompost and pesticide) and is effective as substitute of the synthetic pesticide in coventional cabbage cultivation. Among the various additives, marigold and soursop leaves are most effective based on crop yields and insect attack intensity. The results suggest that the application of vermicomposts with botanical pesticide additives is effective for controlling P. xylostella in the production of organic vegetables.

Disclaimer: None.

Conflict of Interest: None. Source of Funding: None.

\section{References}

Afolayan FID, Adegbolagun OM, Irungu B, Kangethe L, Orwa J and Anumudu CI, 2016. Antimalarial actions of Lawsonia inermis, Tithonia diversifolia and Chromolaena odorata in combination. J. Ethnopharmacol. 191: 188-194.

Ahmad N, Ansari MS and Hasan F, 2012. Effects of neem based insecticides on Plutella xylostella (Linn.). Crop Protection. 34(2012): 18-24.

Ahmad S, Ansari MS and Muslim M, 2015. Toxic effects of neem based insecticides on the fitness of Helicoverpa armigera (Hübner). Crop Protection. 68(2015): 72-78.

Amalia AV and Yusa MH, 2018. Control pest of leaf caterpillars (Plutella xylostella) in delima rose apples using soursop leaf extract (Annona muricata). Jurnal Pendidikan IPA Indonesia. 7(1): 1-8.

Ambrosio SR, Oki Y, Heleno VCG, Chaves JS, Nascimento PGBD, Lichston JE, Constantino MG, Varanda EM and Da Costa FB, 2008. Constituents of glandular trichomes of Tithonia diversifolia: relationships to herbivory and antifeedant activity. Phytochem. 69: 2052-2060. 
Angraeny P, Suprapto C and Yunimar A, 2018. Study of pest attack intensity on commercial Strawberries (Fragaria $x$ ananassa). VIGOR. 3(2): 49-54.

Ansante TF, Do Prado Ribeiro L, Bicalho KU, Fernandes JB, Vieira PC and Vendramim JD, 2015. Secondary metabolites from Neotropical Annonaceae: screening, bioguided fractionation, and toxicity to Spodoptera frugiperda (JE Smith) (Lepidoptera: Noctuidae). Ind. Crops Prod. 74: 969-976.

Arancon NQ, Edwards CA, Bierman P, Metzger JD, Lee S and Welch C, 2003. Effects of vermicomposts on growth and marketable fruits of field-grown tomatoes, peppers and strawberries. Pedobiologia. 47: 731-735.

Asgharnia H, 2003. Comparison of aerobic compost and vermicompost in the view of maturatio time and microbial and chemical quality. The 6th national environmental health congress, Mazandaran, Iran.

Atiyeh RM, Lee S, Edwards CA, Arancon NQ and Metzger JD, 2002. The influence of humic acids derived from earthworm-processed organic wastes on plant growth. Bioresour Technol. 84: 714.

Baidoo PK, Mochiah MB and Apusiga K, 2012. Onion as a pest control intercrop in organic Cabbage (Brassica oleracea) production system in Ghana. Sust. Agric. Res. 1(1). DOI:10.5539/sar.v1n1p36.

Blessing LDT, Colom OA, Popich S, Neske A and Bardón A, 2010. Antifeedant and toxic effects of acetogenins from Annona montana on Spodoptera frugiperda. J. Pest Sci. 83: 307-310.

Calabi-Floody M, Medina J, Rumpel C, Condron LM, Hernandez M, Dumont M and Mora M L, 2018. Smart fertilizers as a strategy for sustainable agriculture. Adv. Agron. 147: 119-157.

Dobson H, Cooper J, Manyangarirwa W, Karuma J and Chiimba W, 2002. Integrated vegetable pest management: safe and sustainable protection of small scale brassicas and tomatoes. Natural Resources Institute (NRI), Kent, UK. p. 179.

Dutta S, 2015. Biopesticides: An ecofriendly approach for pest control. Review Article. World J. Pharm. Pharmaceut. Sci. 4(6): 250-265.

Ferreira MJ, Brant AJ, Alvarenga SAV and Emerenciano VP, 2005. Neural networks in chemosystematic studies of Asteraceae: a classification based on a dichotomic approach, Chem. Biodivers. 2: 633-644.

Freitas AF, Pereira FF, Formagio ASN, Lucchetta JT, Vieira MC and Mussury RM, 2014. Effects of methanolic extracts of annona species on the development and reproduction of Spodoptera frugiperda (J.E. Smith) (Lepidoptera: Noctuidae). Neotrop. Entomol. 43(5): 446-52.

Glare T, Caradus J, Gelernter W, Jackson T, Keyhani N, K€ohl J, Marrone P, Morin L and Stewart A, 2012. Have biopesticides come of age? Trends. Biotech. 30: 250-258.

Goffin E, Zi_emons E, De Mol P, Madureira MC, Martins AP, Cunha AP, Philippe G, Tits M, Angenot L and Frederich M, 2002. In vitro antiplasmodial activity of Tithonia diversifolia and identification of its main active constituent: tagitinin C. Planta Med. 68: 543-545.

Gonçalves GLP, de Cássia Domingues V, do Prado Ribeiro L, Fernandes JB, das Graças Fernandes MDF, Forim MR and Vendramim JD, 2017. Compounds from Duguetia lanceolata St. -Hil. (Annonaceae) bioactive against Zabrotes subfasciatus (Boheman) (Coleoptera: Chrysomelidae: Bruchinae). Ind. Crops Prod. 97: 360-367.

Grzywacz D, Rossbach A, Rauf A, Russel DA, Srinivasan R and Shelto AM, 2010. Current control methods for diamondback moth and other brassica insect pests and the prospects for improved management with lepidopteran resistant $\mathrm{Bt}$ vegetable brassicas in Asia and Africa. Crop Prot. 29: 68-79.

Gupta S and Dikshit AK, 2010. Biopesticides: An ecofriendly approach for pest control. J. Biopesticides. 3(1 Special Issue): 186 - 188.

Hamid, Supartha IW, Susila IW and Sudiarta IP, 2018. Flight behavior, development of population and attack of stone leek leaf miner Liriomyza Chinensis Kato (Diptera: Agromyzidae) towards five varieties of onion (Allium cepa L.). Int. J. Life Sci. 2(2): 51-63.

Isman MB, 2006. Botanical insecticides, deterrents, and repellents in modern agriculture and an increasingly regulated world. Annu. Rev. Entomol. 51: 45-66.

Isman MB and Grieneisen ML, 2014. Botanical insecticide research: many publications, limited useful data. Trends Plant Sci. 19: 140-145.

Jama B, Palm CA, Buresh RJ, Niang A, Gachengo C, Nziguheba G and Amadalo B, 2000. Tithonia 
diversifolia as a green manure for soil fertility improvement in western Kenya: A review. Agroforest. Systems. 49: 201-221.

Koul O, 2004. Neem: a global perspective. In: Koul, O., Wahab, S. (Eds.), Neem: Today and in the New Millennium. Kluwar Academic Publisher, Dordrecht, Boston, London, pp. 1-9.

Labou B, Brevault T, Bordata D and Diarra K, 2016. Determinants of parasitoid assemblages of the diamondback moth, Plutella xylostella, in cabbage farmer fields in Senegal. Crop Protection. 89: 6-11.

Lazcano C and Domínguez J, 2011. The Use of Vermicompost in Sustainable Agriculture: Impact on Plant Growth and Soil Fertility.p.1-23. In: Soil Nutrients ISBN 978-1-61324-785-3 Editor: Mohammad Miransari, Nova Science Publishers, Inc.

Lazcano C, Gomez-Brando $\mathrm{M}$ and Domínguez J, 2008. Comparison of the effectiveness of composting and vermicomposting for the biological stabilization of cattle manure. Chemosphere. 72(7): 1013-1019.

Liang GM, Chen W and Liu TX, 2003. Effects of three neem-based insecticides on diamondback moth (Lepidoptera: Plutellidae). Crop Protection. 22: 333-340.

Liu S, Chen FZ and Zalucki MP, 2002. Development and survival of the diamondback moth (Lepidoptera: Plutellidae) at constant and alternating temperatures. Environ. Entomol. 31: 221-231.

Mwanauta R, Mtei K and Ndakidemi P, 2014. Prospective bioactive compounds from Vernonia amygdalina, Lippia javanica, Dysphania ambrosioides and Tithonia diversifolia in controlling legume insect pests. Agric. Sci. 05: 1129-1139.

Mikami AY and Ventura MU, 2008. Repellent, antifeedant and insecticidal effects of neem oil on Microtheca punctigera. Braz. Arch. Biol. Technol. 51(6): 1121-1126.

Nurhidayati N, Ali U and Murwani I, 2016. Yield and quality of cabbage (Brassica oleracea L. var. Capitata) under organic growing media using vermicompost and earthworm Pontocolex corethrurus inoculation. Agric. Agric. Sci. Procedia. 11(2016): 5 -13

Nurhidayati N, Ali U and Murwani I, 2017. Chemical composition of vermicompost made from organic wastes through the vermicomposting and composting with the addition of fish meal and egg shells flour. J. Pure Appl. Chem. Res. 6(2): 172136.

Nurhidayati N, Machfudz M and Murwani I, 2018. Direct and residual effect of various vermicompost on soil nutrient and nutrient uptake dynamics and productivity of four mustard Pak-Coi (Brassica rapa L.) sequences in organic farming system. Int. J. Recycl. Org. Waste Agric. 7: 173-181.

Oyewole IO, Ibidapo CA, Moronkola DO, Oduola AO, Adeoye GO, Anyasor GN and Obansa JA, 2008. Anti-malarial and repellent activities of Tithonia diversifolia (Hemsl.) leaf extracts. J. Med. Plants Res. 2:171-175.

Pavela R, Dall'Acqua S, Sut S, Baldan V, Kamte SLN, Biapa Nya PC, Cappellacci L, Petrelli R, Nicoletti M, Canale A, Maggi F and Benelli G, 2018. Oviposition inhibitory activity of the Mexican sunflower Tithonia diversifolia (Asteraceae) polar extracts against the two-spotted spider mite Tetranychus urticae (Tetranychidae). Physiol. Mol. Plant Pathol. 101: 85-92.

Prakash A and Rao J, 1997. Botanical pesticides in agriculture. CRC Lewis Publs. Boca Raton, USA. p. 481.

Qamar SR, Haroon A, Saif and Raza MS, 2017. Effect of different pests on the crop of Brassica Oleracea (Cauliflower) in Faisalabad. J. Biodiver. Environ. Sci. 11(4): 157-163.

Ravindran B, Contreras-Ramos SM and Sekaran G, 2015. Changes in earthworm gut associated enzymes and microbial diversity on the treatment of fermented tannery waste using epigeic earthworm Eudrilus eugeniae. Ecol. Eng. 74: 394401.

Ribeiro LP, Santos MS, Gonçalves GLP and Vendramim JD, 2015. Toxicity of an acetogeninbased bioinsecticide against Diaphorina citri (Hemiptera: Liviidae) and its parasitoid Tamarixia radiata (Hymenoptera: Eulophidae). Florida Entomol. 98: 835-842.

Ribeiro LP, de Souza CM, Bicalho KU, Baldin ELP, Forim MR, Fernandes JB and Vendramim JD, 2017. The potential use of Annona (Annonaceae) by products as a source of botanical insecticides. Buletin SEEA. 2017(02): 26-29.

Talekar NS and Shelto AM, 1996. Biology, ecology, and management of the Diamondback moth. Annu. Rev. Entomol. 38: 275-301. 
Thakore Y, 2006. The biopesticide market for global agricultural use. Ind. Biotech. 2: 194-208.

Sarfraz M, Dosdall LM and Keddie BA, 2006. Diamondback moth-host plant interactions: implications for pest management. Crop Prot. 25: 625-639.

Schmutterer H, 1997. Side-effects of neem (Azadirachta indica) products on insect pathogens and natural enemies of spider mites and insects. J. Appl. Entomol. 121: 121-128.

Souza CM, Baldin EL, Ribeiro LP, Silva IF, Morando R, Bicalho KU and Fernandes JB, 2017. Lethal and growth inhibitory activities of Neotropical Annonaceae-derived extracts, commercial formulation, and an isolated acetogenin against Helicoverpa armigera. J. Pest Sci. 90(2): 701709.
Sow G, Diarra K, Arvanitakis L and Bordat D, 2013. The relationship between the diamondback moth, climatic factors, cabbage crops and natural enemies in a tropical area. Folia Hort. 25/1: 3-12. DOI: 10.2478/fhort-2013-0001.

\section{Contribution of Authors}

Nurhidayati: Conceived idea, designed research methodology, data collection, data analysis and manuscript writing

Machfudz M: Statistical analysis, literature review and manuscript writing

Basit A: Data collection, data interpretation, literature search and manuscript writing Handoko RNS: Literature review, data interpretation, manuscript writing, manuscript final reading and approval 